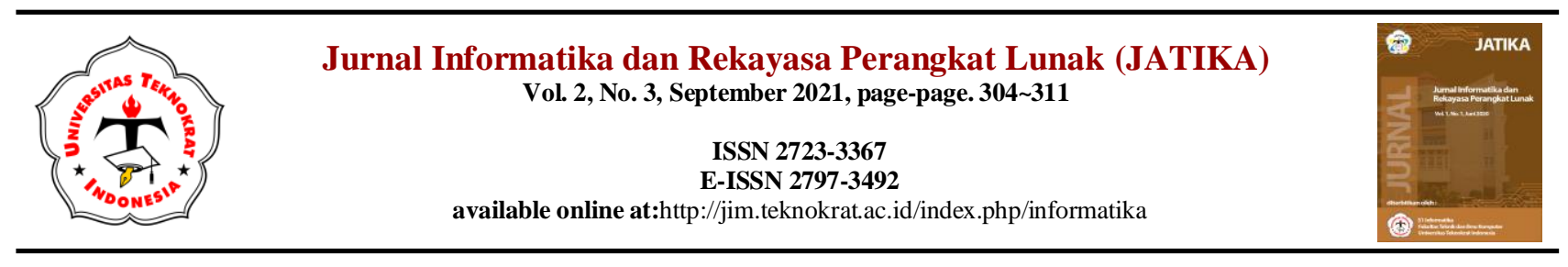

\title{
RANCANG BANGUN APLIKASI PENJUALAN GROSIR SEMBAKO PADA TOKO LA-RIS
}

\author{
Muhammad Iqbal Maliki ${ }^{1}$, Suaidah $^{2}$, Parjito $^{3}$ \\ Informatika ${ }^{l}$, Universitas Teknokrat Indonesia \\ Informatika ${ }^{2}$, Universitas Teknokrat Indonesia \\ Informatika ${ }^{3}$, Universitas Teknokrat Indonesia
}

Muhammadiqbalmaliki@gmail.com, Suaidah@teknokrat.ac.id, Parjito@teknokrat.ac.id

Published: 30 September 2021

\begin{abstract}
E-commerce or in Indonesian, namely electronic commerce is the distribution, purchase, sale, marketing of goods and services through electronic systems such as the internet or television, www, or other computer networks. E-commerce may involve electronic fund transfers, electronic data exchange, automated inventory management systems, and automated data collection systems. At this time, the LA-RIS Store has not used the e-commerce facility so that it is difficult to offer products to consumers who are outside the city. In addition, it can also have an impact on the product sales process, namely the ignorance of consumers who are outside the city of the existence of the LA-RIS Store. The sales process of the LA-RIS Store will only be carried out if there are consumers who come to the store, while many consumers who are outside the city do not know the existence of the LA-RIS Store. To build this e-commerce system, the tools used to describe the system model are in the form of Use case diagrams, Activity Diagrams, and Class Diagrams. Using the PHP programming language and MYSQL database. With this e-commerce, it is hoped that it will make it easier for consumers to obtain information about product specifications offered by the LA-RIS Store. Make it easier for LA-RIS stores to offer or sell their products to consumers who are outside the city. Consumers who are outside the city can find out the existence of the LA-RIS store by using this e-commerce service and can order without having to come to the store. Make it easier for consumers in the payment process because there are several options in the payment process. With a good product data processing or management system and equipped with security, it will support the performance of the system.
\end{abstract}

Keyword : E-commerce, Online Store, PHP, MySQL, Mobile E-commerce, Mobile Application

\begin{abstract}
Abstrak
E-commerce atau dalam bahasa Indonesia yaitu perdagangan elektronik adalah penyebaran, pembelian, penjualan, pemasaran barang dan jasa melalui sistem elektronik seperti internet atau televisi, www, atau jaringan komputer lainnya. E-dagang dapat melibatkan transfer dana elektronik, pertukaran data elektronik, sistem manajemen inventori otomatis, dan sistem pengumpulan data otomatis. Pada saat ini, Toko LA-RIS belum menggunakan fasilitas e-commerce tersebut sehingga kesulitan dalam menawarkan produk kepada konsumen yang berada di luar kota. Selain itu, juga bisa mengakibatkan dampak yang berpengaruh kepada proses penjualan produk yaitu ketidaktahuan konsumen yang berada di luar kota akan keberadaan Toko LARIS. Proses penjualan Toko LA-RIS akan hanya dilakukan apabila terdapat konsumen yang datang ke toko tersebut, sedangkan banyak konsumen yang di luar kota yang tidak tahu keberadaan Toko LA-RIS. Untuk membangun sistem e-commerce ini, alat yang digunakan untuk menggambarkan model sistem adalah berupa diagram Use case diagram, Activity Diagram, dan Class Diagram. Menggunakan bahasa pemrograman PHP dan Database MySQL. Dengan adanya e-commerce tersebut diharapkan dapat memudahkan konsumen memperoleh informasi mengenai spesifikasi produk yang ditawarkan oleh Toko LA-RIS. Memudahkan toko LA-RIS dalam menawarkan atau menjual produknya kepada konsumen yang berada di luar kota. Konsumen yang berada di luar kota dapat mengetahui keberadaan toko LA-RIS dengan menggunakan layanan $e$ commerce ini serta bisa memesan tanpa harus datang ke toko. Memudahkan konsumen dalam proses pembayaran karena terdapat beberapa pilihan dalam proses pembayaran tersebut. Dengan adanya sistem pengolahan atau manajemen data produk yang baik serta dilengkapi keamanan, maka akan mendukung kinerja dari sistem tersebut.
\end{abstract}

Keyword : E-commerce, Toko Online, $\mathrm{PHP}, \mathrm{MySQL}$, E-commerce Mobile, Mobile Application 
To cite this article:

M. Iqbal M., Suaidah, Parjito (2021). RANCANG BANGUN APLIKASI PENJUALAN GROSIR SEMBAKO PADA TOKO LA-RIS. Jurnal Informatika dan Rekayasa Perangkat Lunak, Vol(2) No(3), 304-311.

\section{PENDAHULUAN}

Perkembangan teknologi saat ini berjalan dengan cepatnya, dan banyak sekali keuntungan yang bisa di dapatkan dari perkembangan teknologi informasi ini. Menurut Swastha, (1996) Grosir (wholesaler) adalah suatu unit usaha yang membeli dan menjual kembali produknya kepada para pengusaha (yang bukan end-user) dan menurut Dirjen Bea Cukai retailer adalah orang yang membeli barang dalam jumlah besar kemudian dijual kembali kepada pembeli individu contoh retailer adalah supermarket, departement stores, retail shop, car dealer dsb.

Untuk pengolahan data menjadi informasi salah satu contohnya adalah pengolahan data menggunakan komputer maka proses pengolahannya akan menjadi lebih cepat dan hasilnya jauh lebih baik dari pada tanpa menggunakan komputer. Pada dasarnya ada dua jenis pedagang yaitu pedagang besar atau grosir dan pedagang kecil atau retailer. Pedagang besar atau grosir adalah pedagang yang menjual barang ke pedagang kecil atau eceran, penjual lain seperti industri, institusi, serta pengguna komersial dalam jumlah besar, akan tetapi tidak sampai ke konsumen akhir. grosir biasanya membeli barang langsung ke produsen dalam jumlah besar, contohnya seperti distributor dan agen.

Sementara retailer atau pedagang kecil/eceran adalah pedagang yang menjual barang langsung kepada konsumen akhir yang mengonsumsi barang tersebut untuk keperluan pribadi dan bukan untuk tujuan usaha dimana penjualan ke setiap konsumen biasanya dalam jumlah kecil. Retailer dapat dikatakan sebagai penghubung antara produsen sebagai penghasil produk dengan konsumen akhir. Contohnya seperti minimarket, toko kelontong, warung, dan lain sebagainya. Toko LA-RIS adalah toko yang berkegiatan sebagai wholesaler (grosir) yang berlokasi di Gedong Tataan, Pesawaran. Toko LA-RIS melayani berbagai pemesanan barang sembako seperti beras, gula, tepung, telor dan lain sebagainya. Seiring dengan perkembangan perusahaan penjualan terus meningkat sehingga terjadi kerumunan dan antrian yang cukup panjang diarea penjualan perusahaan. Hal ini memang sudah biasa terjadi namun karena terjadinya pandemic Covid-19 atau dikenal sebagai (Corona) perusahaan tidak boleh lagi membiarkan terjadinya kerumunan dan antrian panjang pada area penjualan Toko LA-RIS.

Perkembangan teknologi saat ini dan ditambahnya wabah Covid-19 menjadikan Toko LA-RIS untuk mengikuti kemajuan teknologi dengan tujuan mengurangi timbulnya kerumunan dan antrian panjang pada area penjualan. Hal ini memberikan ide untuk melakukan perancangan yang dapat menjadi wadah untuk melakukan jual beli sembako secara online dan pembeli tidak perlu lagi antri pada area penjualan Toko LA-RIS karena setelah pemesanan dilakukan barang akan dikiriman oleh kurir internal perusahaan ke alamat toko retail yang dituju. Sistem aplikasi adalah memberikan fasilitas untuk memesan produk yang ingin dibeli oleh toko retail melalui aplikasi mobile dengan adanya fasilitas tersebut toko retail tidak perlu datang ke lokasi, sedangkan aplikasi akan memfasilitasi operator toko dengan memberikan informasi pemesanan secara lengkap.

\section{TELAAH PUSTAKA \\ E-Commerse}

E-commerce merupakan proses membeli, menjual, atau memperdagangkan data, barang, atau jasa melalui internet (Turban et al., 2015: 7). E-commerce didefinisikan sebagai transaksi komersial yang melibatkan pertukaran nilai yang dilakukan melalui atau menggunakan tekonologi digital antara individu (Laudon dan Traver, 2017: 8-9). Media e-commerce melibatkan penggunaan internet, world wide web, dan aplikasi atau browser pada perangkat selular atau mobile untuk bertransaksi bisnis. Platform mobile adalah pengembangan terbaru dalam infrastruktur Internet dari berbagai perangkat mobile seperti smartphone dan tablet melalui jaringan nirkabel (wifi) atau layanan telepon seluler. Pada awal berkembangnya $e$-commerce, satu-satunya media digital adalah web browser, namun saat ini media yang lebih banyak digunakan adalah melalui aplikasi mobile (Laudon dan Traver, 2017: 11-12).

\section{Klasifikasi E-Commerse}

Laudon dan Traver (2017: 22-27) mengklasifikasikan e-commerce menjadi enam jenis model, yaitu:

1. Business-to-consumer (B2C) e-commerce, merupakan jenis e-commerce yang paling sering dibahas, di mana bisnis online jenis ini menjangkau konsumen individual.

2. Business-to-business (B2B) e-commerce, merupakan jenis $e$-commerce terbesar yang berfokus pada penjualan ke bisnis lain. Proses transaksi e-commerce bertipe B2B melibatkan perusahaan atau organisasi yang dapat bertindak sebagai pembeli atau penjual.

3. Consumer-to-consumer (C2C) e-commerce, merupakan jenis yang menyediakan media bagi konsumen untuk menjual satu sama lain, dengan bantuan pembuat pasar online (juga disebut penyedia platform). Dalam C2C $e$ commerce, pihak individu menjual barang atau jasanya kepada individu, organisasi atau perusahaan yang berperan sebagai konsumen melalui Internet. 
4. Mobile e-commerce (m-commerce), mengacu pada penggunaan perangkat mobile untuk memungkinkan bertransaksi online dengan menggunakan jaringan seluler dan nirkabel untuk menghubungkan smartphone atau tablet ke internet.

5. Social e-commerce, merupakan e-commerce yang menggunakan jejaring sosial dan social media.

6. Local e-commerce, merupakan bentuk e-commerce yang berfokus untuk melibatkan konsumen berdasarkan lokasi geografis saat ini. Pedagang lokal menggunakan berbagai teknik pemasaran online untuk mendorong konsumen ke toko mereka.

\section{Komponen E-commerse}

Komponen atau pilar pendukung e-commerce menurut Turban et al. (2015: 9) adalah sebagai berikut:

1. Manusia. Penjual, pembeli, perantara, sistem informasi dan pakar teknologi, karyawan lain, dan peserta lainnya.

2. Kebijakan publik. Masalah hukum dan kebijakan lain dan peraturan, seperti perlindungan privasi dan perpajakan, yang ditentuk oleh pemerintah, termasuk standar teknis dan kepatuhan.

3. Pemasaran dan periklanan. Seperti bisnis lainnya, e-commerce biasanya membutuhkan dukungan pemasaran dan periklanan. Hal ini sangat penting dalam transaksi online $\mathrm{B} 2 \mathrm{C}$, di mana pembeli dan penjual biasanya tidak saling mengenal.

4. Layanan pendukung. Banyak layanan dibutuhkan untuk mendukung e-commerce. Ini berkisar dari pembuatan konten hingga pembayaran hingga pengiriman pesanan.

5. Kemitraan bisnis. Usaha patungan, pertukaran, dan kemitraan bisnis dari berbagai jenis umum terjadi di $e$ commerce. Ini sering terjadi di seluruh rantai pasokan yaitu, interaksi antara perusahaan dan pemasoknya, konsumen, dan mitra lainnya.

\section{Grosir}

Grosir adalah adalah suatu unit usaha yang membeli dan menjual kembali produknya kepada para pengusaha (yang bukan end-user) dan menurut Dirjen Bea Cukai retailer adalah orang yang membeli barang dalam jumlah besar kemudian dijual kembali kepada pembeli individu. Contoh retailer adalah supermarket, departement store, retail shop, car dealer dsb (Swastha, 1996).

\section{Mobile}

Aplikasi mobile adalah aplikasi yang bisa digunakan secara berpindah-pindah tempat (mobile) sehingga anda bisa menikmati aplikasi ini kapan pun dan dimana pun. Untuk pengembangan secara mobile, J2ME (Java 2 Micro Edition) merupakan program yang menggunakan bahasa pemrograman java yang komponen nya terdiri dari java virtual machine (JVM) yang digunakan untuk menjalankan program java pada emulator atau handheld device dan Java API (Application Programming interface) dan tools lain yang untuk mengembangkan aplikasi java seperti Java Emulator, Emulator Motorola, dari J2ME Wireless Toolkit (Komputer, 2014). Aplikasi mobile juga dapat diartikan sebagai aplikasi perangkat lunak yang dibuat khusus untuk dijalankan di dalam tablet atau smartphone. Umumnya developer mobile apps memerlukan IDE atau Integrated Development enviroments untuk pengembangan aplikasi mobile itu sendiri (Irwansyah \& V. Moniaga, 2014).

\section{PHP}

PHP merupakan bahasa pemrograman berbasis web yang memiliki kemampuan untuk memproses data dinamis. PHP dikatakan sebagai sebuah server-side embedded script language artinya sintaks-sintaks dan perintah yang kita berikan akan sepenuhnya dijalankan oleh server tetapi disertakan pada halaman HTML biasa. Aplikasi-aplikasi yang dibangun oleh PHP pada umumnya akan memberikan hasil pada web browser, tetapi prosesnya secara keseluruhan dijalankan di server (Lestanti \& Susana, 2016).

\section{Android}

Android adalah sebuah sistem operasi yang sengaja diciptakan untuk perangkat mobile berbasis Linux yang mencakup sistem operasi, middleware, dan aplikasi Android menyediakan platform terbuka bagi para pengembang untuk menciptakan aplikasi mereka. Awalnya Google Inc. membeli Android Inc. yang membuat perangkat lunak untuk ponsel pintar/smartphone. Kemudian untuk mengembangkan Android, dibentuklah Open Handset Alliance (OHA).

\section{Platform Google Android}

Platform Android adalah sebuah software stack produksi google untuk perangkat mobile yang terdiri atas sistem operasi, middleware, dan key applications. Aplikasi Android dapat dikembangkan melalui Android Standart Development Kit (Android SDK) menggunakan sintaks bahasa pemrograman Java. Aplikasi Android nantinya tidak akan berjalan langsung diatas kernel sistem operasi namun berjalan diatas Dalvik, yaitu sebuah virtual machine yang khusus dirancang untuk digunakan pada sistem embedded (Mazharuddin, 2011). 
1. Applications dan Widgets

Applications and Widgets adalah layer yang membatasi penggunanya hanya untuk berhubungan dengan aplikasi saja, seperti halnya saat pengguna mengunduh aplikasi kemudian melakukan instalasi dan menjalankan aplikasi tersebut.

2. Applications Frameworks

Pengembang memiliki akses penuh menuju API framework seperti yang dilakukan oleh aplikasi yang berkategori inti. Komponen yang termasuk di dalam Applications Frameworks yaitu Views, Content Provider, Resource Manager, Notifications Manager, Activity Manager.

3. Linux Kernel

Linux Kernel adalah layer inti dari sistem operasi Android itu berada. Berisi file-file sistem yang mengatur system processing, memory, resource, drivers, dan sistem-sistem operasi Android lainnya. Linux kernel yang digunakan Android adalah Linux Kernel release 2.6.

\section{METODE PENELITIAN}

\section{Alur Penelitian}

Penelitian dilakukan berdasarkan diagram alir metodologi, dibawah ini adalah gambar alur penelitian, yaitu:

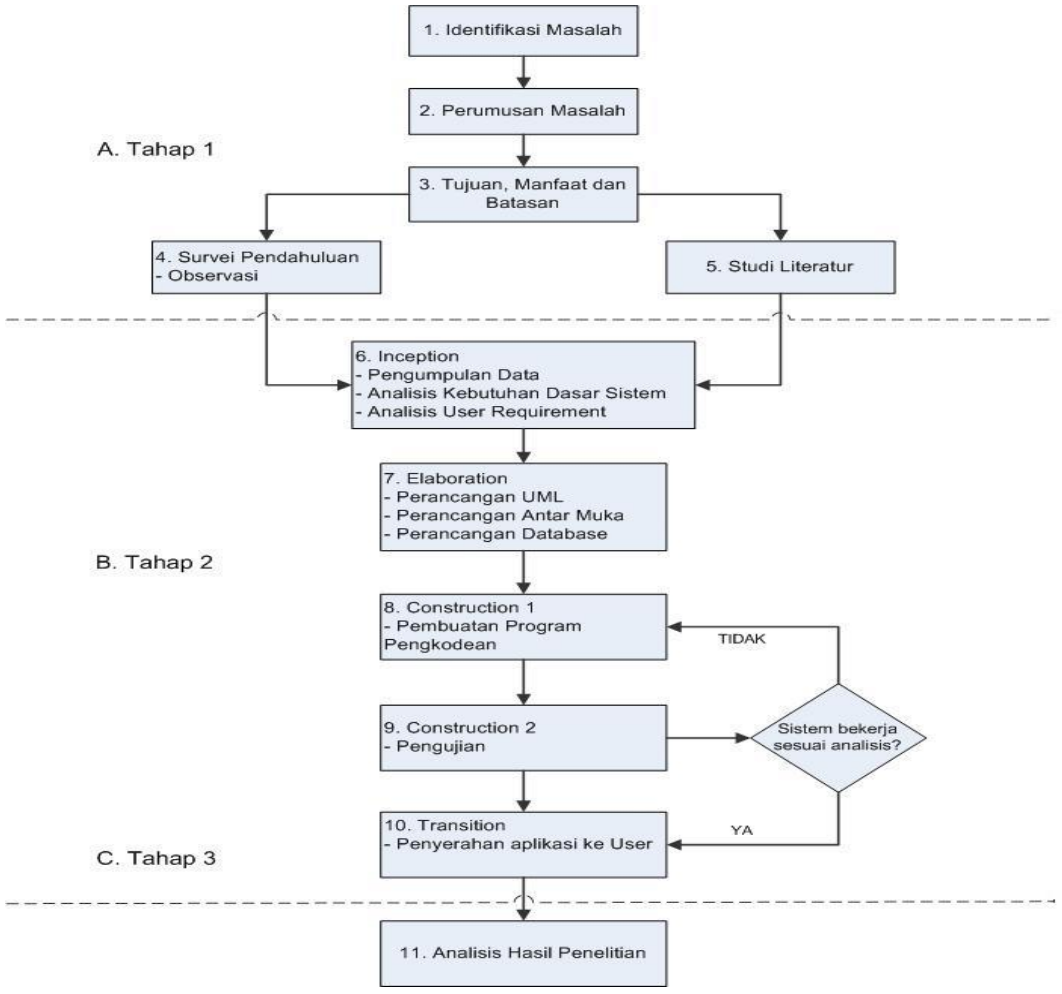

Gambar 1. Alur Penelitian

Sumber : Deby Ariyandi, FMIPA Universitas Lampung, 2016)

\section{Teknik Pengumpulan Data}

Pengumpulan data yang dilakukan pada penelitian ini untuk digunakan membantu kelancaran dalam penyususnan penelitian dan diperlulakan suatu metode yang digunakan dalam penelitian ini adalah sebagai berikut:

Tinjauan Pustaka (Library Research)

Metode pengumpulan data atau informasi yang dilakukan dengan cara mempelajari berbagai laporan-laporan ilmiah, jurnal penelitian dan dokumen atau sumber bacaan serta buku-buku referensi yang berkaitan atau berhubungan dengan topik usulan penelitian yang sedang diteliti.

\section{Pengembangan Sistem}

Perancangan Use Case Diagram

Use case digunakan untuk mengetahui fungsi apa saja yang ada di dalam sebuah sistem dan siapa saja yang berhak menggunakan fungsi-fungsi tersebut. Dibawah ini adalah gambar dari rancangan use case diagram, yaitu: 


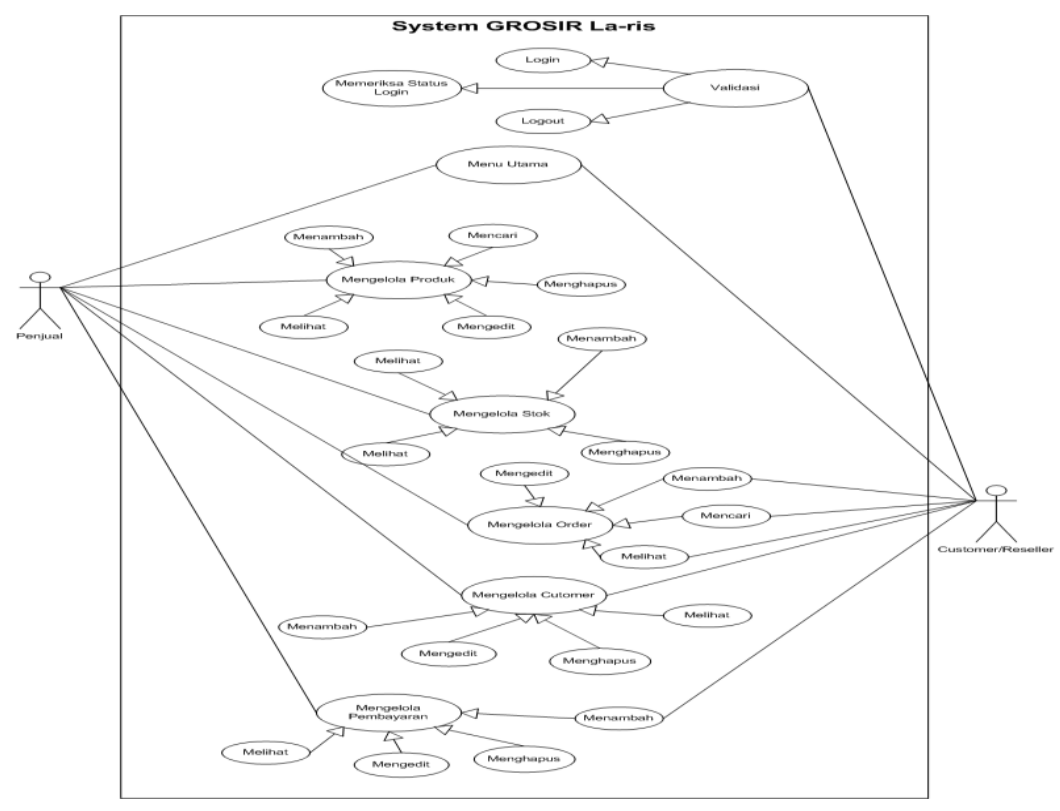

Gambar 1. Use case Diagram

\section{ANALISIS DAN PEMBAHASAN \\ Implementasi \\ Form Login Costumer}

Form login costumer merupakan tampilan awal yang digunakan untuk masuk kedalam website dan belanja online, berikut adalah form login costumer pada gambar dibawah ini.

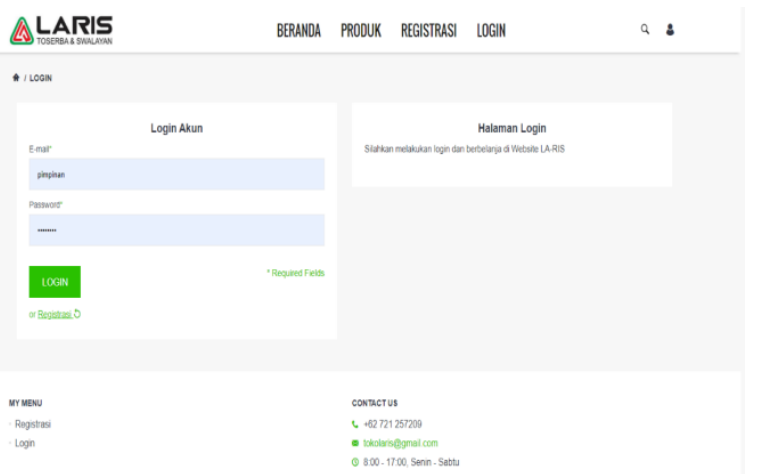

\section{Form Registrasi Costumer}

Gambar 2. Login Costumer

Form registrasi costumer digunakan costumer untuk melakukan registrasi registrasi agar bisa belanja online dengan mengisi data diri sesuai dengan kartu identitas diri. Berikut tampilan form registrasi pada gambar dibawah ini sebagai berikut.

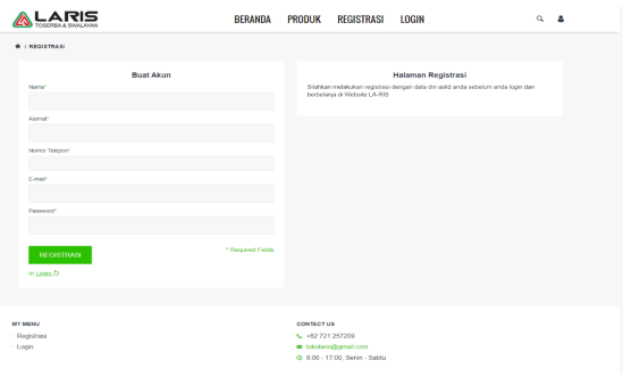

Gambar 3. Registrasi Costumer 


\section{Form Halaman Utama Admin}

Halaman utama admin berfungsi untuk mengakses menu-menu lainnya yang terdapat pada sistem, berikut tampilan halaman utaa admin pada gambar berikut.

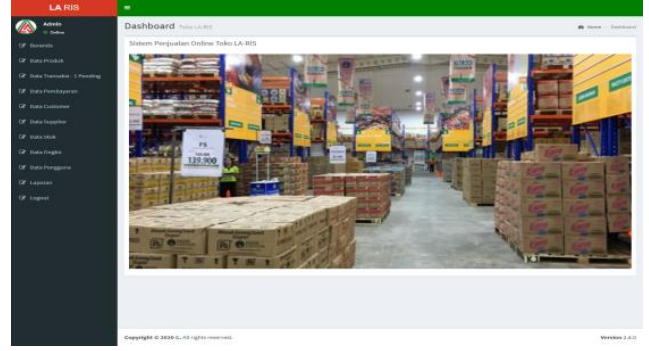

Gambar 4. Halaman Utama Admin

Form Halaman Beranda Costumer

Halaman beranda costumer berfungsi untuk daftar produk terbaru dan terpopuler. Berikut tampilan halaman beranda costumer pada gambar berikut.

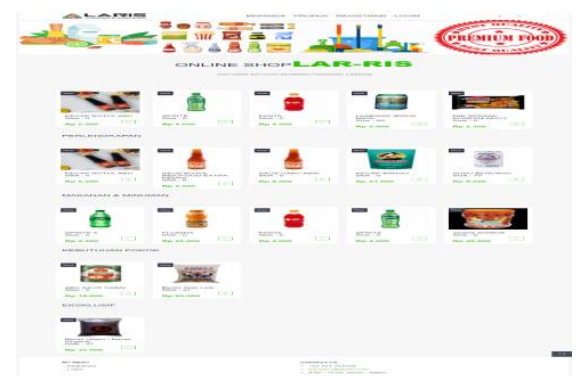

Gambar 5. Halaman Beranda Costumer

\section{Form Halaman Keranjang Belanja}

Halaman keranjang belanja berfungsi untuk menampilkan daftar produk yang akan di beli oleh costumer. Berikut tampilan halaman keranjang belanja costumer pada gambar sebagai berikut.

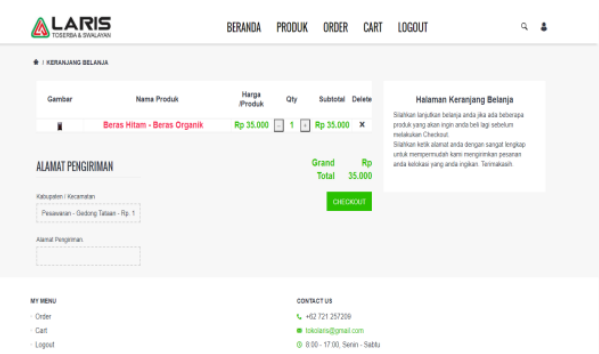

Gambar 6. Halaman Keranjang Belanja

\section{Form Halaman Order}

Halaman daftar order berfungsi untuk menampilkan daftar interface yang telah dilakukan oleh costumer. Berikut tampilan halaman daftar interface pada gambar berikut.

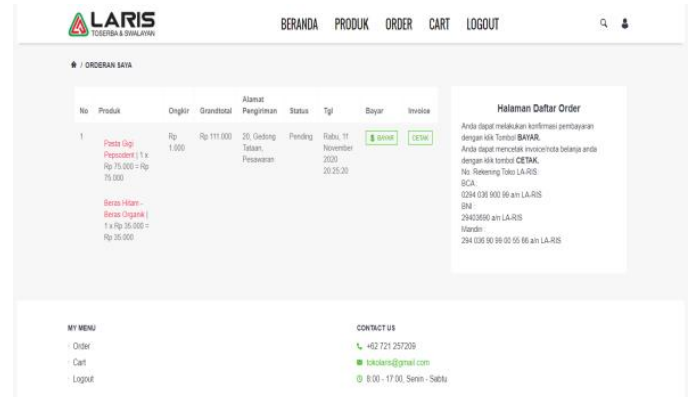

Gambar 7. Halaman Order 


\section{Form Daftar Produk}

Halaman daftar produk berfungsi untuk menampilkan daftar produk yang bisa dibeli oleh costumer. Berikut tampilan halaman daftar produk pada gambar dibawah ini.

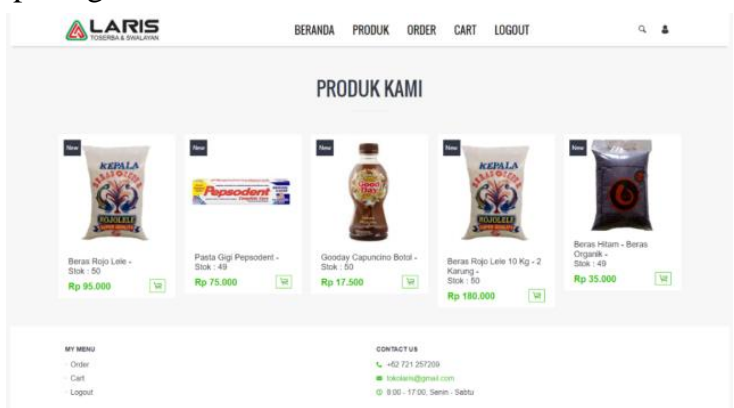

Gambar 8. Daftar Produk

\section{Form Konfirmasi Pembayaran}

Form konfirmasi pembayaran digunakan untuk mengirim bukti transfer costumer kepada admin. Berikut tampilan form pembayaran pada gambar berikut.

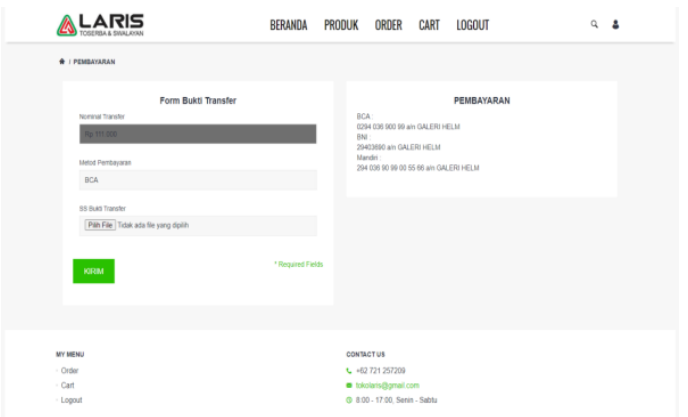

Gambar 9. Konfirmasi Pembayaran

\section{Pengujian Black Box}

Pengujian dilakukan menggunakan Blackbox Testing dengan menguji semua unit sistem. Tujuan dari pengujian ini adalah untuk mengetahui apakah sistem yang dibangun sesuai dengan kebutuhan dan layak untuk digunakan. Blackbox Testing merupakan pengujian yang mengabaikan mekanisme internal sebuah sistem dan berfokus pada fungsi - fungsi yang dimiliki oleh perangkat lunak yang dibangun. Pengujian dilakukan oleh 5 responden, yaitu 1 orang dengan profesi admin Toko LA-RIS, 2 karyawan toko LA-RIS, 2 orang pembeli dan 1 dosen pembimbing. Untuk menguji semua fungsional yang ada di dalam sistem seperti pengujian admin apakah sistem sesuai dengan rancangan awal berikut adalah hasil pengujian black box yang telah dilakukan. Total pertanyaan kuisioner Blackbox yaitu melibatkan 5 responden dengan sebanyak 29 pertanyaan sehingga total pertanyaan

$$
5 \times 29=75
$$

Pertanyaan. dan menghasilkan jawaban diterima sebanyak 195 dan ditolak 12. Sehingga dapat dihitung :

$$
\begin{gathered}
\begin{array}{c}
\text { Skor Aktual : } 195 \\
\text { Skor Ideal }: 12
\end{array} \\
\text { \% Skor Aktual }=\frac{12}{195} \times 100 \% \\
\text { \% Skor Aktual }=94 \%
\end{gathered}
$$

Berdasarkan perhitungan tersebut diperoleh nilai hasil pengujian sebesar 94\%. Menurut Toko LA-RIS hasil pengujian sistem lebih dari $80 \%$. Nilai dari hasil pengujian dapat dikatakan berhasil dan layak digunakan dalam proses jual beli online. 


\section{SIMPULAN}

Berdasarkan uraian dari bab-bab yang telah dijelaskan, penulis menarik kesimpulan dari beberapa masalah yaitu :

1. Aplikasi penjualan online pada Toko LA-RIS ini mampu mempermudah proses jual beli baik itu secara online maupun offline. Serta membantu dalam mengontrol stok barang dan mempermudah costumer dalam berbelanja tanpa harus berkerumuman di toko.

2. Sistem penjualan online ini dirancang menggunakan bahasa pemrograman PHP dengan database MySQL dan dimodelkan dengam UML seperti Use case, Sequance Diagram dan Class Diagram yang dimuat dalam Web sehingga menghasilkan sebuah sistem penjualan online yang bermanfaat bagi Toko LA-RIS dan costumer.

3. Berdasarkan hasil dari pengujian menggunakan Blackbox dengan menguji pada aspek Fungsionality menunjukan bahwa sistem dapat melakukan 94\% fungsinya dengan benar, yang berarti bahwa sistem layak digunakan.

\section{UCAPAN TERIMA KASIH}

Puji syukur penulis panjatkan doa kepada Tuhan YME, karena atas berkat dan rahmat-Nya, penulis dapat menyelesaikan penelitian dengan judul "Rancang Bangun Aplikasi Penjualan Grosir Sembako Pada Toko LA-RIS" Penulis juga mengucapkan terima kasih kepada:

1. Bapak Dr.H.M. Nasrullah Yusuf, S.E., M.BA. selaku Rektor Universitas Teknokrat Indonesia.

2. Bapak Dr.H. Mahathir Muhammad, S.E., M.M. selaku Dekan Fakultas Teknik dan Ilmu Komputer.

3. Ibu Dyah Ayu Megawaty, M. Kom. selaku Ketua Program Studi S1 Informatika Fakultas Teknik dan Ilmu Komputer Universitas Teknokrat Indonesia.

\section{REFERENSI / DAFTAR PUSTAKA}

Aditya Rahmatullah Pratama. 2016. Belajar UML - Sequence Diagram. https://www.codepolitan.com/belajar-umlsequence-diagram57fdb1a5ba777-17044. Diakses pada tanggal 7 April 2020

Adi Sulistyo Nugroho. ( 2016 ). E-commerce Teori dan Implementasi. Yogyakarta: EKUILIBRIA

Alifvia Arvi N., Kodrat Iman Satoto, Rinta Kridalukmana, (2018), Perancangan Aplikasi Toko Online "XO-LICIOUS" Berbasis Mobile Web pada Sistem Operasi Android, Program Studi Sistem Komputer, Fakultas Teknik, Unviersitas Diponegoro.

Ahmad Imaduddin, (2018). Menjadi Android Developer Expert, DICODING.

Clune, T.L., R.B. Rood. 2011. Software Testing and Verification In ClimateModel Development. IEEE Journal, Focus: Climate Change Software.

C, K, Laudon., Traver. (2017). E-commerce 2014, 10th Edition. Pearson

Hendi Wijaya, Wellia Shinta Sari, (2015) Rancang Bangun Mobile Commerce Berbasis Android Pada Toko Duta Buku Semarang, Sistem Informasi Fakultas Ilmu Komputer.

Kasmawi, Diah Anggraini Fitri, Mansur, Widya Syahputri (2019), Aplikasi Jual Beli Online Produk Usaha Kecil dan Menengah Berbasis Android, JURNAL INSTEK.

Marjito, Gina Tesaria, (2016) Aplikasi Penjualan Online Berbasis Android, Jurnal Computech \& Bisnis.

Muhammad Faisal Widad, (2017) Sistem Informasi Penjualan Berbasis Android di Toko Busana Fasial Collection, Fakutlas Teknik Komputer UKI, Bandung.

Rosa A.S dan M.Shalahuddin. 2011. Modul Pembelajaran Rekayasa PerangkatLunak (Terstruktur dan Berorientasi Objek. Bandung.

Shalahuddin, M. dan Rosa A.S., 2015. Modul Pembelajaran Rekayasa Perangkat Lunak: Terstruktur dan Berorientasi Objek. Modula. Bandung.

STMIK. 2015. Buku Panduan Penulisan Proposal Laporan Akhir Studi \& Skripsi, Teknokrat. Bandar Lampung. 